\title{
SOPRON-FERTÓ, AS A PRIORITY TOURISM DEVELOPMENT AREA
}

\section{SOPRON-FERTÓ, MINT KIEMELT TURISZTIKAI FEJLESZTÉSI TÉRSÉG}

\author{
Alexandra Éva Makra', Attila Szabó ${ }^{1}$ \\ Tourism and Catering Department, Business Administration Faculty, John von Neumann University, \\ Hungary
}

\author{
Keywords: \\ Sopron \\ Fertő region \\ priority tourism development area \\ destination management \\ Kulcsszavak: \\ Sopron \\ Fertő-táj \\ kiemelt turisztikai fejlesztési térség \\ desztináció menedzsment
}

\begin{abstract}
In 2016, the organizational management of tourism in Hungary has changed, the basis of which was defined in the CLVI. Tourism Development Act of 2016. The law puts the focus of tourism development on the tourist areas, which aims to make the destinations able to renew their competitive travel offers in the short term for both foreign and domestic guests who are looking for experiences or have higher specific spending. One of the five priority tourism development areas named by the Government until September 2017 is the Sopron-Fertö destination. Based on the 122 completed questionnaires, it can be stated that five towns (Sopron, Bük, Hegykö, Fertöd and Nagycenk) in the Sopron-Fertö priority tourism development area are known among households participating in domestic tourism.

Összefoglalás

2016-ban átalakult a magyarországi turizmus szervezeti irányítása, amelynek alapjait a 2016. évi CLVI. turizmusfejlesztési törvény határozta meg. A törvény a turisztikai fejlesztések fókuszát a turisztikai térségekre helyezi, melynek célja, hogy a fejlesztések révén a desztinációk már rövidtávon képesek legyenek megújulva versenyképes utazási ajánlatot jelenteni az élményeket kereső, akár magasabb fajlagos költéssel bíró külföldi és belföldi vendégek számára egyaránt. A Kormány által 2017 szeptemberéig megnevezett öt kiemelt turisztikai fejlesztési térség közül az egyik a Sopron-Fertő desztináció. A 122 darab kitöltött kérdőív alapján megállapítható, hogy a Sopron-Fertő kiemelt turisztikai fejlesztési térségben jelenleg öt város (Sopron, Bük, Hegykő, Fertőd és Nagycenk) rendelkezik ismertséggel a belföldi turizmusban résztvevő háztartások körében.
\end{abstract}

\section{Introduction}

Tourism has been characterized by steady growth over the past six decades, based on the number of international tourist arrivals, and has become one of the world's largest and fastest growing economic sectors. [Hiba! A hivatkozási forrás nem található.8] In addition to traditional destinations (Europe and North America), many new destinations became better known, driven by the emerging destination-based approach, aiming to make them a more attractive destination for both tourists and investors. The ultimate goal is to turn the target area in 
the tourism market an independent and unique brand. [2] The topic of the development of destination management was first examined by Alastair Morrison in 2003. [15]

In terms of domestic conditions, tourism is characterized by organizational renewal from 2016, the basis of which is defined in the Tourism Development Act. Act CLVI of 2016 on the state responsibilities of the development of tourism areas [11] moves the focus of tourism development from individual attractions to tourist destinations, that is, increasing the tourism potential of Hungary will probably be based on the tourist destination theory. The role of public tourism management in accordance with the destination logic is to delineate individual destinations and develop a specific intervention program for them, build and manage independent brands and brand profiles for destinations that can be identified with a unique experience. The destination approach designated by the Hungarian government ensures the economic, social and environmental sustainability of the developed attractions, as well as provides a quality experience for the visitors and defines the direction of the attraction development and its main content requirements.

As a result of the new approach, the government named five priority tourism development areas in 2016-2017 and a government decision was made on the provision of resources needed for the implementation of the developments. Sopron-Fertő was named a priority tourism development area among the first, on $15^{\text {th }}$ December 2016 [12], and on $27^{\text {th }}$ December [13], developments in the area were also announced.

The resources to be used in tourism development thus concentrate on destinations rather than tourist regions, which has proved to be a pioneering step in comparison with the practice of other Central European states. [3]

\section{Sopron-Fertố priority tourism development area}

\subsection{The characteristics of Sopron-Fertő priority tourism development area and the developments to be implemented}

The area designated on $15^{\text {th }}$ December 2016 consists of 15 municipalities. The municipalities belonging to the priority tourism development area of Sopron-Fertő are: Sopron, Fertőboz, Fertőd, Fertőhomok, Fertőrákos, Fertőszéplak, Hegykő, Hidegség, Sarród including Fertőújlak as well, Fertőszentmiklós, Nagycenk, Röjtökmuzsaj, Sopronhorpács, Zsira, Bük, as well as the area of Fertő-Hanság National Park (Figure 1). The largest of the named municipalities is Sopron (area: $169.04 \mathrm{~km}^{2}$, population: 62 246), the smallest in terms of area is Fertőhomok $\left(12.61 \mathrm{~km}^{2}\right)$ and in terms of total population is Fertőboz (324). The mosaic area of the priority development region is $502.14 \mathrm{~km}^{2}$. It is true for all five major tourist development areas that their territorial coverage does not consist of continuously connected areas. [7]

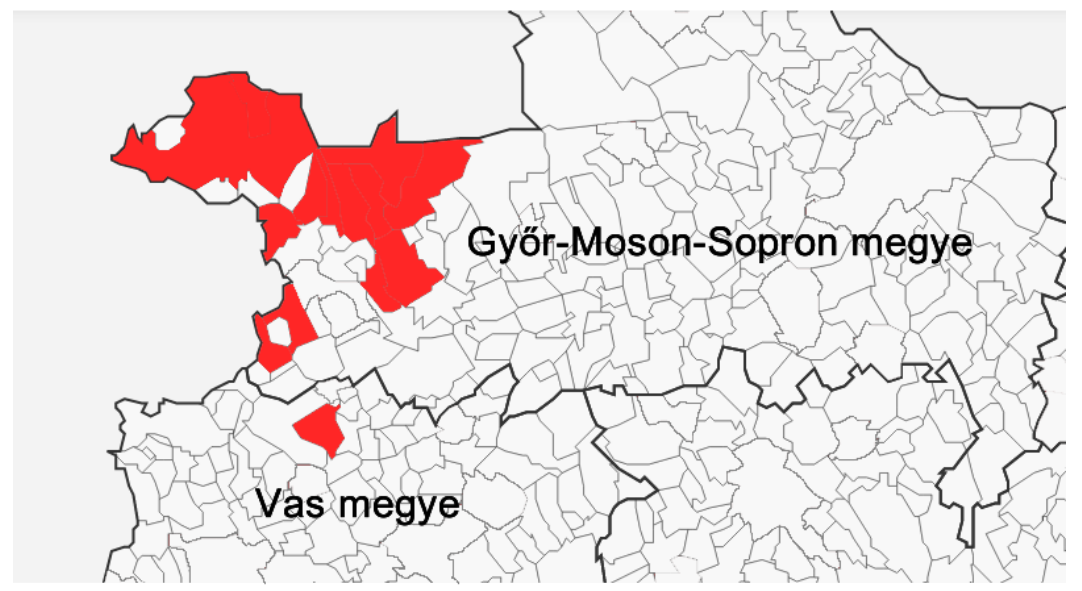

Figure 1. The area of Sopron-Fertö priority tourism development area

Source: own editing 
It is not our goal to describe the tourist competitiveness of Sopron, as it was already done by Krisztián Egyed [5], so we only note that Sopron is the second richest in monuments in Hungary. [9] Health tourism is particularly important in the priority tourism development area. One of the main attractions of the destination is Bükfürdő Thermal and Spa, which is based on medicinal water and health tourism, the spa in Hegykő [6], the spa in Balf and the medical and cosmetic services available in Sopron. [16] In addition to medical services, the attraction of the area is partly the World Heritage Site of Fertő/Neusiedlersee Cultural Landscape [1], as well as historical and cultural monuments. [17]

Over the next decade, close to 60 billion HUF worth of development projects will be implemented in Sopron-Fertő priority tourism development area from European Union and domestic sources. Nearly 10 billion are being allocated to strengthen the tourist attraction of the destination, the source of which is the Economic Development and Innovation Operational Programme (GINOP) co-financed by the European Union. This includes the development of spa facilities in Sopron-Lővérek and Sopron-Balf, as well as in Bükfürdő, the renovations of the Széchenyi Castle in Nagycenk and Esterházy Castle in Fertőd, product and service development in Sopron, development of World Heritage Sites and active tourism networks. The historic city center of Sopron and the cultural heritage protection of the medieval castle district will be developed under the Modern Cities Program. [10] 7.3 billion HUF of domestic resources were allocated for the reconstruction of the downtown medieval castle district. The development of St Michael's Church and Sekrestyésház - the only development from TOP (Territorial and Settlement Development Operational Programme) resources - and the development of many cultural heritage sites for tourism purposes on the Main Square will come from nearly 3 billion HUF of European Union funds. As part of the Modern Cities Program, approximately 16 billion HUF of domestic resources are allocated to the Lővérek Program. The developments included in the program are the construction of an indoor swimming pool, the renewal of the existing pool, the establishment of a National Conference Center with a capacity of 1200, the Lővérek road renovation program and the construction of a bicycle route. The development of the tourist attractiveness of Lake Fertő is also carried out in the framework of Modern Cities Program. The product and service development of Lake Fertő is realized with the help of 8 billion HUF European Union support. An additional 15 billion HUF from domestic resources will be used to create hospitality and accommodation infrastructure, and to develop the basic infrastructure of Lake Fertő and improve water quality.

In the $1527 / 2017$ Government Decision of $14^{\text {th }}$ August 2017 - which includes the second stage of the historic reconstruction and presentation of the historic downtown of Sopron in the framework of the Modern Cities Program, and the implementation of the second stage of the Lővérek Program - the 5.5 billion HUF domestic resource allocated for the construction of the indoor swimming pool under the Lővérek Program was increased to 6.3 billion HUF.

\subsection{Presentation of main tourism statistics in the priority tourism development area}

Based on the information database of the Hungarian Central Statistical Office, we collected the number of guest nights in the accommodations of Sopron-Fertő priority tourism development area, according to the total number of visitors and the number of foreign guests. The purpose of the overview was to compare the period before the establishment of the priority tourism development area (until $31^{\text {st }}$ December 2016) with the first year (2017), when the foundation stones of some of the targeted developments have already been laid, and to draw any conclusions as to whether the area can generate more turnover in the future through the developments and besides boosting domestic tourism, whether the priority tourism development area can become an attractive destination for foreign tourists as well.

In terms of total guest turnover, Bük had the most guest nights in commercial accommodations (741518 in 2017). The number of guest nights in Sopron reached 50\% of Bük's turnover (366 172 in 2017), Hegykő's turnover is also worth mentioning (108 328 in 2017), however, it is only $15 \%$ compared to Bük. Bük is also a leader in terms of foreign guest turnover. More than 50\% of the guest turnover of the two spa towns, Bük and Hegykő is coming from foreign 
guests: on average, $75 \%$ of guests in Hegykő are foreign visitors, while this ratio is $60 \%$ in Bük. On the other hand, it should be noted that out of the municipalities of the Sopron-Ferto" destination, only nine of the local governments have issued tourism tax. [4]

\section{Analysis of Sopron-Fertő tourism development area based on primary questionnaire research}

In the course of our research, we were looking for answers to the questions of how well known the municipalities and attractions of Sopron-Fertő new priority development area are, how important the respondents consider the developments in the region, and whether the investments will have an impact on the respondents' intention to visit in the future. During the primary research, we surveyed the priority tourism development area by questionnaires [8], for which 20 closed questions were asked. The questionnaire was created on the Google Forms page for faster and more efficient access to respondents. The questionnaire could be completed on the online interface between $28^{\text {th }}$ February and $14^{\text {th }}$ March 2018 and 122 replies were received within 15 days. The results of the questionnaires were summarized using Excel.

Based on the results of our primary questionnaire research, the main motivations for domestic leisure recreation are 'entertainment, recreation, relaxation, sports' (Figure 2), thus this is the aspect that has to be met when creating a tourism product that uniformly represents the municipalities of the priority tourism development area on the tourism market and thus presumably increasing the number of tourists arriving in the destination.

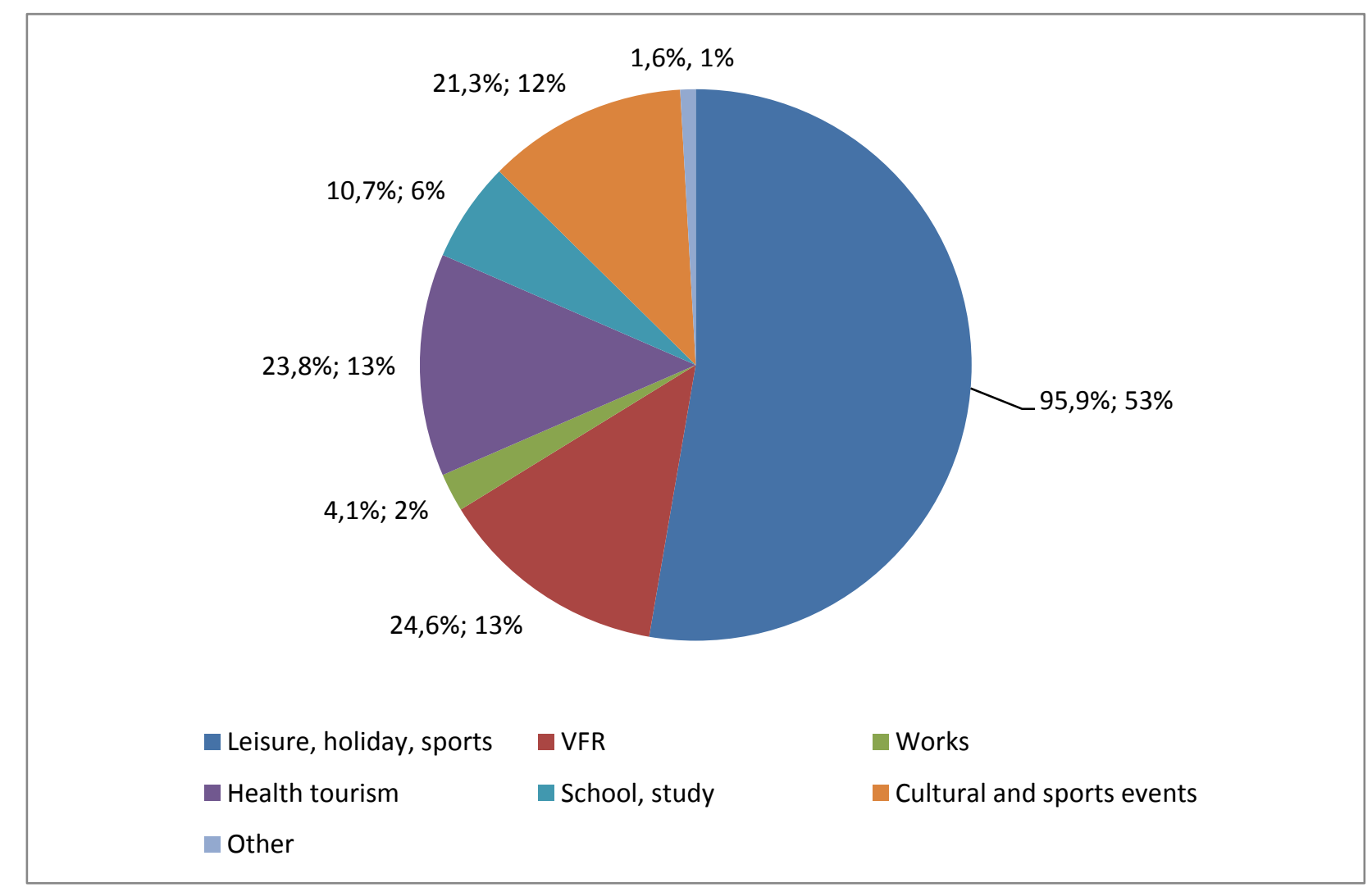

Figure 2. Domestic leisure recreation motivations based on the answers of the respondents

Source: own editing based on the results of the questionnaire survey

The most popular means of transportation during the holiday or on arrival at the venue is the car, which can also be related to the fact that most people go on holiday with their families and this way they can conveniently organize their domestic leisure activities independently of public transportation schedule. Based on the results of the questionnaire, who have already been to Sopron and its surroundings were mostly satisfied with the accessibility of the sites, but most 
answers were only about Sopron, Bük, Fertőd and Nagycenk. During domestic travels, hotels are the mostly used commercial accommodations. Hotels were mainly chosen as preferred accommodation type by respondents with higher monthly net income. The second most popular commercial accommodations are the pensions, which are used by respondents with both more modest or higher monthly income, so we could not determine a typical group based on the responses to the questionnaire. Holiday houses are preferred by respondents with lower monthly income. The majority of respondents participate in domestic tourism at least once a year, but we could not establish a clear correlation between the monthly net income and the frequency of holidays based on the summary of the results.

As far as the definition of destination is concerned, it is not possible to create a specific definition from the tourists' point of view, rather, it is only possible to draw conclusions about the characteristics. According to the responses of the participants in the questionnaire, the most important is the security of the destination, the price/value ratio of the services, the quality of the accommodation types and the information/communication; that is, these are the aspects that will need to be given special attention in the future by the managing body responsible for tourism in the region.

The fact that $65.6 \%$ of the respondents have visited Sopron and its surroundings shows that there are very good prospects for the Sopron-Fertő priority tourism development area, that not only the regional but also the domestic demand may increase due to the developments, and its close proximity to the border allows it to appear on the international market.

Developments in the region were welcomed by the majority of the respondents, and in the future, they would be happy to visit Sopron and its surroundings in the knowledge of the investments. The investment of the National Conference Center and its importance divided the respondents the most, but conference tourism has a significant role not only for the development area but also for the country, as it typically involves guests with higher specific spending, often arriving with their family members. The proximity of Sopron to the Schwechat International Airport - about $70 \mathrm{~km}$ - provides a promising opportunity to host several international conferences in Hungary.

At present, five towns (Sopron, Bük, Hegykő, Fertőd and Nagycenk) in the Sopron-Fertő priority tourism development area are well-known among households participating in domestic tourism.

\section{Summary}

In 2016, the organizational transformation of tourism began, based on the CLVI. Tourism Development Act of 2016. The law puts the focus of tourism development on the tourist areas, with the aim of enabling the destinations to be renewed in the short term through the developments, to be able to provide competitive travel offers for both foreign and domestic guests looking for experiences or having higher specific spending. One of the five priority areas named by the Government until September 2017 is the Sopron-Fertő priority tourism development area.

The Sopron-Fertó priority tourism development area has the potential $-a$ ) favorable geographical location, $b$ ) the architectural and cultural heritage of the municipalities that make up the region, $c$ ) investments in the near future, $d$ ) visibility not only in the regional but also in the national tourism of the country -, to become a promising regional brand on the tourism supply market besides Budapest and Lake Balaton.

\section{Acknowledgement}

We are grateful for the support provided for the research, within the framework of EFOP-3.6.1-16-2016-00006'Development and enhancement of the research potential at John von Neumann University'. The project is supported by the Hungarian Government and the European Union, co-financed by the European Social Fund, and is implemented within the framework of Széchenyi 2020 Program. 


\section{Bibliographical References}

[1] Ambrus, A. - Tolnay, K. (1994): Fertő-Hanság Nemzeti Park. TKM Egyesület, Budapest

[2] Aubert, A. - László, M. (1995): Turizmus tervezés - Turizmus marketing. JPTE Természettudományi Kar Regionális Társadalomföldrajzi Tanszék, Pécs

[3] Bagdi, R. (2017): A turisztikai régiók és desztinációk rendszere Közép-Európában. In: Gradus 4 (2) pp. 495-500.

[4] Bagdi, R. (2019): Destination development along the Austrian-Hungarian border. In: Maria, do Rosário Monteiro, Mário, S. Ming Kong (Ed.) Modernity, Frontiers and Revolutions. Proceedings of the 4th International Multidisciplinary Congress (PHI 2018), CRC Press - Taylor and Francis Group, London, pp. 453-458.

[5] Egyed, K. (2014): Gondolatok a soproni régió turisztikai versenyképességéról. In: Soproni Szemle. 68 (4) pp. 407418.

[6] Géher, P. - Bender, T. - Ákoshegyi, Gy. (2016): Magyarország gyógyfürdői és gyógyvízes termálfürdői. Magyar Balneológiai Egyesület, Budapest

[7] Horvát, D. - Bagdi, R. (2018): A Tokaj, Felső-Tisza és Nyírség kiemelt turisztikai fejlesztési térség jellemzői és lehetséges turisztikai szerepe. In: Gradus, 5 (2) pp. 140-145.

[8] Kmetty, Z.: Kutatásmódszertan és prezentációkészítés. http://igyk.pte.hu/files/tiny_mce/File/kari_projektek/informaciotudaservenyesules/tananyagok/1_alprojekt/KM/ o4 kutatasmodszertan4 kerdoivkeszites.pdf [Downloaded: 16-Mar-2018]

[9] Krisch, M. (2012): Séták Sopronban. Escort Tourist Bt., Sopron

[10] Magyar Közlöny (2015): 1217/2015. (IV. 17.) Korm. határozat Magyarország Kormánya és Sopron Megyei Jogú Város Önkormányzata közötti együttmúködési megállapodás végrehajtásával összefüggő feladatokról. In: Magyar Közlöny (53) pp. 5005.

[11] Magyar Közlöny (2016a): 2016. évi CLVI. törvény a turisztikai térségek fejlesztésének állami feladatairól. In: Magyar Közlöny (203) pp. 82116-82120.

[12] Magyar Közlöny (2016b): 429/2016. (XII. 15.) Korm. rendelet a turisztikai térségek és a kiemelt turisztikai fejlesztési térségek meghatározásáról. In: Magyar Közlöny (203) pp. 82261-82263.

[13] Magyar Közlöny (2016c): 1862/2016. (XII. 27.) Korm. határozat a Sopron-Fertő kiemelt turisztikai fejlesztési térség meghatározásáról és a térségben megvalósítandó egyes fejlesztések megvalósításához szükséges források biztosításáról. In: Magyar Közlöny (217) pp. 84192-84194.

[14] Magyar Közlöny (2017): 1527/2017. (VIII. 14.) Korm. határozat a Modern Városok Program keretében Sopron történelmi belvárosa múemléki felújítása és bemutatása II. üteme, valamint a Lővérek Program II. üteme megvalósításáról. In: Magyar Közlöny (129) pp. 18337-18338.

[15] Morrison, A. (2003): Destination Management and Destination Marketing. The Platform for Excellence in Tourism Destinations. In: Tourism Review 18 (1) pp. 6-9.

[16] Nemzeti Turizmusfejlesztési Stratégia 2030 http://www.kormany.hu/download/8/19/3100o/mtu kiadvany EPUB 297x210mm\%20-\%20preview.pdf [Downloaded: 18-Feb-2018]

[17] Varga, K. (2004): Világörökségünk. World Heritage Sites in Hungary. Kulturális Örökségvédelmi Hivatal, Budapest

[18] UNWTO Tourism Highlights, 2017 Edition https://www.e-unwto.org/doi/pdf/10.18111/9789284419029 [Downloaded: 20-Mar-2018] 